How to cite?

Casero-Ripollés, A., Alonso-Muñoz, L., \& Marcos-García, S. (2021). The Influence of Political Actors in the Digital Public Debate on Twitter About the Negotiations for the Formation of the Government in Spain. American Behavioral Scientist, https://doi.org/10.1177/00027642211003159

\title{
The Influence of Political Actors in the Digital Public Debate on Twitter about the Negotiations for the Formation of the Government in Spain
}

Andreu Casero-Ripollés, Full Professor, Department of Communication Sciences. Universitat Jaume I de Castelló, casero@uji.es

Laura Alonso-Muñoz, Assistant Professor, Department of Communication Sciences. Universitat Jaume I de Castelló, lalonso@uji.es

Silvia Marcos-García, Assistant Professor, Department of Communication Sciences. Universitat Jaume I de Castelló, smarcos@uji.es

\begin{abstract}
Social media has introduced new parameters that can potentially transform the digital political conversation. Traditionally, in the age of mass communication, public debate was dominated by politicians and journalists. However, digital platforms, primarily Twitter, have allowed other social actors to join the political discussion, trying to influence it. The objective of this research is to establish what factors enable the authority and digital influence of political actors in the public debate on Twitter. We use a big data sample of 127.3 million tweets from the negotiation process around the formation of the Government in Spain. The applied methodology is based on social network analysis and machine learning. The results show that ideology, political initiative, and political career are configured as factors capable of conditioning the authority and influence of political actors in the political conversation on Twitter.
\end{abstract}

Keywords: Political Communication, Social Influence, Social Media, Digital Media, Twitter, Political Conversation.

\section{Introduction}

Social media are generating new spaces for public debate. Its growing presence in our society is causing citizens to transfer many of their activities to the digital environment, including political conversation. Its facility to promote connectivity and promote communication flows is generating relevant transformations in political communication. One of the key questions is whether social media can alter the power relations from the mass communication era.

During the second half of the 20th century, political actors were decisive actors in determining the issues, contents, and limits of public debate in conjunction with journalists (Habermas, 2006). That made them great influencers, endowed with the ability to persuade citizens and condition public opinion (McCombs \& Valenzuela, 2020). However, the rise of social media is reconfiguring its position. In this context, it is important to identify the factors that determine and condition the influence and digital authority of politicians in the public debate developed on this digital platform. To do this, 
we use a big data sample of 127.3 million tweets, obtained using the machine learning technique and analyzed using the social network analysis methodology.

\section{The reconfiguration of the influence of political actors on the public debate on Twitter}

Along with journalists, political leaders and parties have traditionally been configured as a crucial actor in political communication. In this conception, the media and politicians are central and indispensable for the creation and articulation of the public sphere (Habermas, 2006). This has placed them as the main protagonists of the political debate in our society and has given them a high capacity to establish the agenda and the predominant frames of the issues capable of capturing the attention of the majority of citizens (McCombs \& Valenzuela, 2020). As a consequence, both actors have enjoyed a high capacity to influence and condition public opinion.

This classic scenario is being deeply altered by the emergence and consolidation of social media. Its ability to introduce new communication dynamics enabling access to the political debate in the digital environment to anybody is transforming the dynamics since the era of mass communication. On the other hand, the growing penetration in different fields and social spheres is providing them a central position in our daily lives. These digital media are increasingly essential to the development of our routines to the point that they have generated a platformization of society (Van Dijck, Poell \& De Waal, 2018). This process is causing a reorganization of the social and political practices around digital platforms. Also, it is placing these devices as a vector of social transformation in our societies in a context of deep mediatization (Hepp, 2019).

A consequence of this is that social media are emerging as new places for political debate for a growing number of social actors (Casero-Ripollés, Micó-Sanz \& Díez-Bosch, 2020). The increased use of these platforms to consume news is making them a relevant forum for public conversation. In this sense, Twitter plays a prominent role because it is the digital medium most oriented towards the dissemination, and discussion, of information and news. Also, it is the favorite place for political actors to communicate (CaseroRipollés, 2018; Jungherr, 2014). As a new scenario, it imposes a new logic and conditions on the political debate and introduces new dynamics that can potentially redefine who and how exerts social influence (Gruz \& Wellman, 2014).

The emergence of Twitter as a place for political debate offers opportunities and risks for political actors. The first advantage is enabling these actors to create and share messages autonomously, without needing the media to communicate to many in an interpersonal way, while reaching a wide audience with a single click. Politicians can thus speak directly to their constituents without relying on third parties (Sobieraj et al., 2020). The immediacy, speed, and brevity of this microblogging platform facilitate selfcommunication focused on the political proposals that make up their electoral program (López-Meri, Marcos-García \& Casero-Ripollés, 2017). Likewise, it offers a channel to express their opinions regarding social issues (Buccoliero, et al., 2020).

Political actors have found on Twitter a way to reach a mass audience using a more personal or intimate side (McGregor, 2018). This strategy is mainly deployed in the candidates' profiles, who take advantage of this platform to assume prominence, build their brand and gain public attention, to the detriment of their parties (Van Aelst, Sheafer \& Stanyer, 2012; López-García, 2016). This can create a sense of connection between 
politicians and citizens, giving way to a communicative strategy based on personal leadership (Chadwick \& Stromer-Galley, 2016).

In this attempt to reach out to their voters, political actors have seen a way to reach a wider audience and even mobilize and persuade their supporters (Enli, 2017). Although parties and politicians do not employ Twitter to promote and encourage dialogue and direct interaction with citizens (Alonso-Muñoz, Marcos-García \& Casero-Ripollés, 2016; Fazekas, et al., 2020), previous literature suggests that social media play a significant role in influencing the behavior of voters (Mora-Cantallops, Sánchez-Alonso \& Visvizi, 2019). Twitter enables the construction of a potentially broad community that identifies with a project and political values (Van Dijck, 2013). Authors such as Tsatsou \& Zhao (2016) even point out how the political commitment created within social media encourages users to become more actively involved and feel part of the political project. Gaining influence in the digital environment is therefore a very valuable resource for political actors. Parties and politicians aspire to condition the online political conversation to influence the agenda and public opinion (Xu et al., 2014).

Consequently, political actors have incorporated Twitter as a common tool to share their messages, especially during electoral campaign periods (Larsson \& Moe, 2012). Therefore, this platform has become a reference to articulate the communication strategies of political actors (Vergeer, Hermans \& Sams, 2013). These actors have found in this medium a way to maximize their ability to approach citizens, directly disseminate their opinions and comments, and improve their public image, thus expanding the range of instruments that they can employ for their self-promotion (Jungherr, 2014).

However, Twitter also entails challenges for political actors. The main one is the increase in competition when articulating and conditioning the political debate. As opposed to a restricted and limited scenario characteristic of mass communication, in which political actors assumed a dominant role, social media have opened the public discussion to new actors, becoming a more open and competitive scenario (Casero-Ripollés, 2018; Feenstra et al., 2017). The ease of accessibility and low economic cost enabled the entry of new participants to these platforms, many of them previously located on the periphery of the political system capable of producing and disseminating content and information to take part in the conversation (Castells, 2013; Chadwick, 2017).

This rise in competition challenges both the place and the influence capacity of political actors in the political debate on Twitter. Some research affirms that this phenomenon is causing a breakdown of the monopoly of the political elite, and also of the conventional media, on political discussion and the articulation of public opinion (Chadwick, 2017; Casero-Ripollés, 2020). This fact would lead to a weakening of their authority and social influence that would lead to the appearance of more difficulties to persuade and convince citizens. However, other authors dispute this thesis of the response of the traditional actors. Taking into consideration the prominence of the rules of the attention economy, on Twitter, although all users can access the political conversation, not all have the same options to effectively condition it (Dagoula, 2019). On digital platforms, it is easy to claim influence, but not so easy to exercise it successfully (Gruzd \& Wellman, 2014). Consequently, from this perspective, social media, and Twitter, in particular, tend to reinforce the authority of those actors, such as politicians, who already occupied a central role in the discussion networks (Valente \& Pumpuang, 2017). 


\section{Method}

\subsection{Sample and Data}

The main objective of this research is to identify the determining factors that condition the digital authority obtained by political actors in the conversation generated on Twitter. Specifically, we want to know if factors such as 1) Digital Popularity; 2) Political Ideology; 3) Political Initiative; 4) Political Career; and 5) Electoral Support condition the digital authority that political actors acquire in the political debate on Twitter about the formation of a Government after the elections.

The methodology applied in this research is based on social network analysis (SNA). This approach is appropriate for analyzing the interactions and relationships between political communication actors (Tong \& Zuo, 2021). The machine learning technique is applied blending automatic coding with a manual one. Employing specifically designed algorithms, we have identified the messages published on Twitter concerning the negotiation process of Government formation after the elections in Spain. Subsequently, the tweets obtained were reviewed and refined to guarantee the relevance of the sample. To measure digital authority, the eigenvector centrality has been used as an indicator of measurement (Bonacich, 2007). It measures the centrality of a user within a particular social media. To do this, the software assigns scores between 0 and 1 to all users of a network according to their degree of direct or indirect connection with other users. Those with higher scores have a greater capacity to condition the conversation since they are better connected in the network.

The sample refers to a highly relevant political event produced after the elections: the negotiation process for the Government formation. The case of Spain between 2015 and 2016 has been marked as the object of study. The analyzed period runs from December 20, 2015, the day the elections were held, to the dissolution of the Spanish Parliament, and the calling of new elections on May 3, 2016, after the failure of the negotiations. Thus, 133 days have been analyzed.

To obtain the data, 145 Twitter profiles from the political and journalistic fields were used. The selection was determined considering their relevance in Spanish political life. Therefore, it is a strategic sample. In a second phase, the followers of these 145 profiles, which together account for 24 million profiles, have been incorporated into the analysis. The size of the sample of tweets derived from this set of profiles made its study unfeasible. For this reason, we decided to limit the analysis to the 30,000 most influential profiles by applying a PageRank calculation (Page et al., 1999). After manual review, duplicate profiles and bots have been removed. Thus, the total of Twitter profiles analyzed has been 24,389 accounts. The tweets generated by these users during the period studied were a total of 127.3 million messages, which is configured as the final sample of this research.

The sample has been collected from three networks or political communities, corresponding to three Spanish cities. This choice is based on the number of the population and its relevance to Spanish political life and its different relationship with the centers of power. Madrid, the capital of Spain, with 3.1 million inhabitants in 2016, is the headquarters of the political institutions of the State such as the Parliament or the Government. Madrid is the center of political life. Secondly, the city of Barcelona has been selected, with 1.6 million inhabitants, which in recent years has experienced the rise of an independence process that aspires to create a new country separate from Spain. Finally, the city of Valencia has been included, with 787,000 inhabitants, which occupies 
a peripheral position with respect to the political, economic, and media centers of power. In each of these networks, the most influential users have been analyzed in terms of their digital authority. In some cases, the same Twitter user manages to be present in two or all three networks simultaneously, while in others, they only manage to access one with sufficient digital authority.

Despite being a large variety of profiles in the sample, we have focused only on political actors. Within this group, three types have been defined: a) candidates, who correspond to the leaders of the parties that have stood in the elections; b) other politicians, which incorporates the rest of the individual political actors; and c) political parties, which includes the profiles of political organizations. Subsequently, a classification has been made to separate individual actors (candidates and other politicians) and groups (parties). To meet our objectives, a specific sample comprised of the 250 political profiles with the highest eigenvector centrality has been extracted from the general sample. To determine the factors that most decisively condition the political debate on Twitter, Pearson correlations have been made, whose values range between -1 and 1 , between the digital authority of the political profiles included in the sample and five variables: digital popularity, political ideology, political initiative, political career and electoral support (votes).

\subsection{Measurements}

\section{Digital Popularity}

Digital popularity is related to the visibility that a specific user acquires within a network. The main element of this indicator is the number of followers. Thus, the larger the number of followers of a user, the greater its impact on the circulation of information and its popularity on the Internet. However, when we talk about Twitter, some previous research (Cha et al., 2010) has highlighted that having a very high number of followers does not necessarily imply influencing the conversation. The popularity measure applied in this research is the Follower Rank, the standardized version of the traditional in-degree measure (Probst, Grosswiele \& Pfleger, 2013). The formula to calculate the Follower Rank is the following: Number of followers of the user / Number of followers of the user + Number of followed by the user. This indicator ranges from 0 to 1 . The closer to the maximum value, the higher the popularity of a user.

\section{Political Ideology}

Political ideology is the set of ideas, values, and fundamental postulates that define a political party regarding the functioning of a society and its institutions. In this research, the analyzed political actors have been classified according to the following ideological divisions: left-wing (1), right-wing (2), or independentists (3). This last category includes political actors who seek to create their state and separate from Spain.

\section{Political Initiative}

The degree of political initiative refers to the position taken by the analyzed political actors regarding the negotiation for the formation of a Government after the elections. In this analysis, the political initiative was taken by the Socialist Party (PSOE) and its leaders, in charge of leading the negotiations to obtain the support of the rest of the political forces present in the Spanish Parliament to try to govern. In this case, the political actors have been classified according to whether they led the negotiation $(1$, in the case of PSOE and its members) or not ( 0 , the rest of the parties and their members). 


\section{Political Career}

The political career refers to the parties' historical path, and it is determined by their year of creation. In the Spanish case, until the 2015 elections, only those political organizations from the period of recovery of democracy at the end of the 1970s, endowed with a long tradition, had entered the Parliament. However, in 2014 new political parties were created and obtained seats in the Parliament. Podemos emerged on the left, and Ciudadanos on the right. Therefore, depending on their history, political actors have been classified as traditional (1) or emerging (2).

\section{Electoral support (votes)}

Voting for a political option refers to the level of support a political option gets from the public in elections. The measure used to calculate this indicator is the percentage of the vote obtained by Spanish political parties in the elections held in December 2015. For this, official data provided by the Ministry of Home Affairs of the Spanish Government have been used ${ }^{1}$.

\subsection{Spain as a case of study}

The general elections held in Spain in December 2015 were significant as two new political parties emerged: Podemos and Ciudadanos. The appearance of these new parties marked the end of the dominant bipartisanship in the last 40 years, embodied by the Popular Party and the Socialist Party (Orriols \& Cordero, 2016; Barberá, Barrio \& Rodríguez-Teruel, 2019; Marcos-Marne, Plaza-Colodro \& Freybug, 2020). The elections held in December 2015 resulted in a highly fragmented Parliament where many political options won representation. This aspect forced all the parties with representation to open a negotiation process to elect a Prime Minister. In this context, the Socialist Party (PSOE) took the lead in the talks to form a new government. However, no agreement was reached, and the socialist candidate, Pedro Sánchez, did not obtain the necessary support to become the Prime Minister. This fact led to the dissolution of Parliament in May, and new elections were called. New elections were held on June 26, 2016.

Meanwhile, since 2012 Catalonia has experienced a complex political process in which a large percentage of Catalan society supports the independence of the territory from the Spanish State (Micó \& Carbonell, 2017). From that moment onwards, a political and civic movement was launched to create a state of its own. This has led the Catalan proindependence parties to incorporate this issue as a priority on their political agenda. In consequence, this issue has transcended to the national political agenda.

\section{Results: Conditioning factors of the conversation about the formation of a Government after the elections on Twitter}

The main objective of this research is to know what factors are determining for a political actor to achieve greater digital authority in the debate generated on Twitter about the formation of a Government after the elections. To do so, Pearson correlations have been made between eigencentrality and five variables: (1) Digital Popularity; (2) Political Ideology; (3) Political Initiative; (4) Political Career; and (5) Electoral Support. The correlations of these factors with digital authority have been developed in each of the political communities studied: Madrid, Barcelona, and Valencia (Table 1). Likewise, individual actors (candidates and other politicians) have been grouped in a single category and groups (parties) in another. The results obtained demonstrate different operating dynamics between the three networks. 
Table 1. Correlations between the factors analyzed and digital authority by political network

\begin{tabular}{|l|c|c|c|c|c|c|}
\hline & \multicolumn{2}{|c|}{ Madrid } & \multicolumn{2}{c|}{ Barcelona } & \multicolumn{2}{c|}{ Valencia } \\
\hline & $\begin{array}{c}\text { Political } \\
\text { Parties }\end{array}$ & $\begin{array}{c}\text { Candidates } \\
\text { and Other } \\
\text { Politicians }\end{array}$ & $\begin{array}{c}\text { Political } \\
\text { Parties }\end{array}$ & $\begin{array}{c}\text { Candidates } \\
\text { and Other } \\
\text { Politicians }\end{array}$ & $\begin{array}{c}\text { Political } \\
\text { Parties }\end{array}$ & $\begin{array}{c}\text { Candidates } \\
\text { and Other } \\
\text { Politicians }\end{array}$ \\
\hline $\begin{array}{l}\text { Digital } \\
\text { Popularity }\end{array}$ & 0.436 & 0.389 & -0.750 & -0.134 & 0.418 & 0.001 \\
\hline $\begin{array}{l}\text { Political } \\
\text { Ideology }\end{array}$ & -0.483 & -0.332 & 0.966 & 0.659 & -0.366 & -0.629 \\
\hline $\begin{array}{l}\text { Political } \\
\text { Initiative }\end{array}$ & 0.902 & 0.067 & -0.592 & -0.360 & 0,970 & 0.830 \\
\hline $\begin{array}{l}\text { Political } \\
\text { Career }\end{array}$ & -0.745 & 0.028 & -0.523 & -0.344 & -0.447 & -0.326 \\
\hline $\begin{array}{l}\text { Electoral } \\
\text { Support }\end{array}$ & -0.182 & -0.144 & -0.515 & -0.315 & 0.017 & -0.380 \\
\hline
\end{tabular}

Source: made by authors

\subsection{Digital Popularity}

Popularity, measured with the Follower Rank, is not a determining factor to condition the conversation on Twitter according to the data obtained (Table 1). However, slight differences are detected depending on the context of the digital debate in which it is inserted. In other words, the characteristics of each network studied and articulated around one of the three cities that conform the sample, slightly determine the results.

The Barcelona network is conditioned by the prominence of the independence movement. Here, we found out that a high level of Follower Rank does not involve a high digital authority on Twitter. This is more significant in the case of the parties $(r=-0.750 ; p<.01)$, since the independentist organizations, despite having a smaller number of followers, obtain high values of eigenvector centrality. This fact determines its important ability to influence the political discussion about the formation of the State Government on Twitter. On the other hand, the Spanish parties, which obtain a higher Follower Rank, have a lower incidence in the political debate on this network. The analysis of the candidates and the other politicians in Barcelona $(\mathrm{r}=-0.134 ; \mathrm{p}<.01)$ offers the same pattern. Although the correlation is less intense, greater popularity is not associated with greater digital authority.

In the cases of the networks of Madrid, the political center of the country, on the one hand, and Valencia, which occupies a peripheral political position, on the other, the results reveal the absence of correlation between popularity and digital authority concerning candidates and other politicians (Table 1). However, the case of political parties presents a difference. Both in Madrid $(r=0.436 ; \mathrm{p}<.01)$ and Valencia $(\mathrm{r}=0.476$; $\mathrm{p}<.01)$ it is observed that the relationship between popularity and the parties' digital authority is relevant, although it assumes moderate values. Therefore, there is a connection between popularity and authority in these actors to condition the debate, although at a low level (Table 1).

\subsection{Political Ideology}


Data shows that the ideology of political actors is a key factor in determining their digital authority on Twitter (Table 1). This is especially relevant in the Barcelona network, where local parties propose a political project based on independence from Spain. The proindependence parties ( $\mathrm{r} 0.966 ; \mathrm{p}<.01$ ) have the largest capacity to condition the debate about the formation of a Government on Twitter. The case of Esquerra Republicana de Catalunya (ERC) stands out, as it obtains an eigenvector very close to one $(E C=0.990440785)$ within this political community. In contrast, the Socialist Party $(E C=0.174360535)$, which nominates its candidate as a potential president for the Spanish Government, has a low level of digital authority. The data reveal that in this network, the digital authority and the ideology of the candidates and other politicians $(r=0.660 ; \mathrm{p}<.01)$ are also correlated, but with a lower intensity than the parties. In this context, the proindependence politicians obtain a greater eigenvector centrality. This is the case of Oriol Amorós $(\mathrm{EC}=1)$, ERC deputy in the Parliament of Catalonia, or Oriol Junqueras $(\mathrm{EC}=0.8782900236)$, leader of this party. Consequently, despite the fact that the discussion revolves around a Spanish event, the pro-independence parties and politicians have the highest influence on the conversation on Twitter in this political community.

On the other hand, in the networks of Madrid and Valencia, left-wing political options have the highest capacity to condition the debate on the formation of the Government on Twitter (Table 1). In Madrid, the relationship between digital authority and ideology is larger in the case of the parties $(\mathrm{r}=-0.483 ; \mathrm{p}<.01)$ than in the candidates and the rest of the politicians $(\mathrm{r}=-0.332 ; \mathrm{p}<.01)$. The case of the Socialist Party $(\mathrm{EC}=0.945235956)$ and Pedro Sánchez $(\mathrm{EC}=0.833164395)$ is particularly noteworthy. These are the left-wing political actors who achieve greater digital authority. However, among the actors with a higher eigenvector centrality in the Madrid network, there are also other left-wing parties such as Podemos $(\mathrm{EC}=0.538953733)$ or Izquierda Unida (IU) $(\mathrm{EC}=0.692618237)$, and their leaders, Pablo Iglesias $(\mathrm{EC}=0.72669794)$ and Alberto Garzón $(\mathrm{EC}=0.70632856)$, respectively.

On the Valencia network, the pattern is similar. Left-wing politicians and parties obtain the highest values of influence in the political debate on Twitter about the formation of the Government after the elections. Here, the relationship between digital authority and ideology is especially notable concerning candidates and other politicians ( $\mathrm{r}=-0.630$; $\mathrm{p}<.01)$. In this political community, the politicians who obtain greater authority are members of the Socialist Party (PSOE), the organization that leads the formation of the Government. Thus, the first positions are held by Ángeles Álvarez $(\mathrm{EC}=0.952002703)$, deputy for Madrid; Carmen Montón $(E C=0.944740604)$, at that time Minister of Health and Public Health in the Valencian Community; and the socialist candidate Pedro Sánchez $(\mathrm{EC}=0.942920373)$. In the case of the parties $(\mathrm{r}=-0.366 ; \mathrm{p}<.01)$, the correlation reaches lower values, although it is also observed that the left-wing parties have the highest digital authority on Twitter. Particularly noteworthy is the Socialist Party, whose eigenvector centrality is 1 , as well as Izquierda Unida (IU) $(\mathrm{EC}=0.440900275)$ and Compromís ( $\mathrm{EC}=0.368310262)$, a local left-wing party.

\subsection{Political Initiative}

The degree of political initiative, that is, the position adopted by political actors in the negotiations for the formation of a Government in the political sphere is also a key factor that determines the digital authority in the conversation on Twitter (Table 1). This correlation is especially strong with respect to political parties in the networks of Madrid $(\mathrm{r}=0.902 ; \mathrm{p}<.01)$ and Valencia $(\mathrm{r}=0.969 ; \mathrm{p}<.01)$. In both cases, the Socialist Party 
(PSOE), who took the initiative in the negotiations on the formation of a Government, obtained the highest digital authority on Twitter both in the political community of Madrid $(\mathrm{EC}=0.945235956)$ and Valencia $(\mathrm{EC}=1)$. In this last network, we also observe that the correlation values are high with regard to the candidates and the other politicians $(\mathrm{r}=0.826 ; \mathrm{p}<.01)$.

In the political community of Barcelona, in which the pro-independence political options have a greater presence, the effect is the opposite: they are the parties $(r=-0.592 ; \mathrm{p}<.01)$ and the politicians $(\mathrm{r}=0.360 ; \mathrm{p}<.01)$ that have a secondary role in the negotiations for the formation of the Government, those that have a greater digital authority in the debate on Twitter (Table 1). Thus, pro-independence political actors, such as Esquerra Republicana de Catalunya (ERC) $(\mathrm{EC}=0.990440785)$ and Junts pel Si $(\mathrm{JxS})(\mathrm{EC}=0.738721906)$, can condition the digital discussion around a relevant aspect at the state level such as the formation of a Government after the elections.

\subsection{Political Career}

The data show that the political career is related to its digital authority on Twitter (Table 1). Political actors with a broader history have more influence on the debate generated on this platform regarding the formation of a Government. By contrast, emerging parties and their candidates achieve less digital authority. A dynamic that is repeated in a very similar way in the three networks analyzed.

In the Barcelona and Valencia networks, we find similar results both in the case of parties and politicians (Table 1). In the political community of Barcelona, the parties $(\mathrm{r}=-0.523$; $\mathrm{p}<.01)$ more consolidated in the Catalan political system, and their leaders $(\mathrm{r}=-0.344$; $\mathrm{p}<.01$ ) have more capacity to condition the digital conversation (Table 1). In this case, there is a coincidence. In addition to the Socialist Party (PSOE), the parties with the longest tradition in Catalonia are those with a pro-independence tendency such as Esquerra Republicana de Catalunya $(\mathrm{ERC})(\mathrm{EC}=0.990440785)$ and Junts pel Si $(\mathrm{JxS})$ $(\mathrm{EC}=0.738721906)$, formerly called Convergència i Unió (CiU). Besides, candidates and politicians who belong to these parties obtain higher levels of digital authority.

In the network of Valencia, digital authority is also related to the career of parties $(\mathrm{r}=0.447 ; \mathrm{p}<.01)$ and politicians $(\mathrm{r}=-0.326 ; \mathrm{p}<.01)$. Once again, the most consolidated political options in the Spanish political system obtain the greatest capacity to influence the discussion on Twitter. Two examples of this are the traditional political parties in the Spanish case: the Socialist Party (PSOE) $(\mathrm{EC}=1)$ and the Popular Party (PP) $(\mathrm{EC}=0.462457444)$.

In the political community of Madrid, the correlation between the career and the digital authority is the most accentuated, primarily in the case of political parties ( $\mathrm{r}=-0.745$; $\mathrm{p}<.01$ ). In this political network, it is the traditional parties, the Socialist Party (PSOE) ( $\mathrm{EC}=0.945235956)$, the Popular Party (PP) $(\mathrm{EC}=0.639033026)$, and Izquierda Unida (IU) $(\mathrm{EC}=0.692618237)$, which have greater digital authority and dominate the conversation on Twitter. On the contrary, the emerging forces play a secondary role in the debate generated in this social media. In this sense, Podemos $(\mathrm{EC}=0.538953733)$ and Ciudadanos $(\mathrm{EC}=0.505002104)$ achieve lower eigenvector centrality values than those achieved by parties with a longer historical path. However, in the case of the candidates and other politicians $(\mathrm{r}=0.028 ; \mathrm{p}<.01)$ of this political community we do not have enough 
evidence to consider that their political career is a conditioning factor of digital authority on Twitter.

\subsection{Electoral Support}

Finally, the percentage of votes obtained in the elections is not a determining factor of the digital authority on Twitter in the networks of Madrid and Valencia. However, in the political community of Barcelona, the data indicate that there is a relationship (Table 1). In this last network, the result of the correlations shows that the electoral support received has a moderate influence on the digital authority of political actors on Twitter. The data show that both parties $(\mathrm{r}=-0.515 ; \mathrm{p}<.01)$ and candidates as well as other politicians $(\mathrm{r}=0.315 ; \mathrm{p}<.01)$ with a lower percentage of the vote have greater digital authority on this platform. In this case, the pro-independence parties such as Esquerra Republicana de Catalunya (ERC) (15.98\% of votes) or Junts pel Si (JxS) $(15.08 \%$ of votes) are the ones who acquire stronger relevance in the debate generated on Twitter about the formation of a Government after the elections.

In the Madrid network, the data reveal that the least voted political options ( $\mathrm{r}=-0.182$; $\mathrm{p}<.01)$, and also their candidates and other politicians $(\mathrm{r}=-0.144 ; \mathrm{p}<.01)$, are the ones that obtain a higher eigenvector centrality (Table 1). In this sense, the winner of the elections was the Popular Party (PP) (33.46\% of votes), which obtained a significantly higher percentage of the vote than the rest of the political options. However, it was the Socialist Party (PSOE) (17.88\% of votes), Podemos (20.86\% of votes), or Ciudadanos (18.80\% of votes) who achieved the highest digital authority on Twitter.

In the political community of Valencia, the effect of the percentage of the votes on the digital authority is similar to the case of Madrid. The less voted candidates and the other politicians $(\mathrm{r}=-0.380 ; \mathrm{p}<.01)$ obtain a higher digital authority in the debate on Twitter (Table 1). The Socialist Party (PSOE) and its members (19.84\% of the votes) have the largest capacity to influence the political conversation on this platform, despite obtaining a much lower percentage of the votes than its competitors, such as the Popular Party (PP) $(31.30 \%)$ or Podemos $(25.09 \%)$. Therefore, getting more votes in the elections does not ensure more possibilities to condition the political discussion on Twitter generated after the elections.

\section{Conclusion and Discussion}

Our findings offer several original contributions to the research field of social media, public debate, and digital political communication. Our first contribution shows that digital popularity, measured through the Follower Rank, is not a factor capable of conditioning the political conversation on Twitter. The correlation data indicate that owning more popularity or followers in the digital environment does not lead to having greater digital authority. The case of the Barcelona network is especially noteworthy, characterized by the political process that demands independence from Spain. In this political community, the independentists, whose Follower Rank is lower, acquire a priority role in the debate on the formation of a Government after the elections on Twitter.

A second relevant finding is that the ideology of political actors is a central factor in gaining influence in the political debate on Twitter. The data suggest that left-wing political actors, on the one hand, and pro-independence parties, on the other, obtain greater digital authority than right-wing political actors. Previous investigations have obtained similar results in the case of the media (Casero-Ripollés, 2020). This indicates 
that ideology is a variable with a powerful capacity to condition digital authority in the political conversation of the different actors of political communication.

Third, the political initiative is also related to the ability to condition political debate in the digital environment. Thus, the political actors who lead the negotiations for the formation of the Government (Pedro Sánchez and the Socialist Party) obtain a greater centrality in the debate generated on Twitter on this issue. Consequently, actors capable of leading political action, in our case those trying to reach a Government pact, acquire more digital authority and more resources to condition the conversation on this platform.

The fourth contribution of our analysis is the following idea: the career of political actors is related to their digital authority. The political actors with more history within the Spanish political system have a more prominent role in the debate on Twitter about the formation of Government, therefore achieving stronger influence. On the other hand, emerging political parties and leaders are at a second level (Valente \& Pumpuang, 2017). The historical career emerges as a determining factor of the centrality of the network. However, concerning the media, the pure players, whose appearance is more recent, manage to surpass the legacy media in the digital political conversation in digital authority (Casero-Ripollés, 2020).

Finally, our findings show that the percentage of the vote is not a determining factor to attain a greater digital authority to direct the political conversation about the formation of the Government on Twitter. However, these results are not conclusive since the strength of the correlation is low or moderate in some specific cases.

Lastly, the data show that the socio-political context decisively conditions the political debate on Twitter. Both the actors with more digital authority and the factors that determine it are decidedly affected by what occurs outside the digital environment. The best example is the Barcelona network. The results about this political community are affected by the process that pursues the independence of Spain that began in 2012. As a result, the most influential political actors on Twitter are the independentists, unlike those actors from other networks such as Madrid or Valencia. Likewise, this also affects the factors that determine the digital authority. Consequently, we can affirm that in the dynamics of influence within this digital platform, the external context is highly important.

These results permit us to advance in the knowledge about the influence capacity of political actors on the political conversation in the digital environment. Our research enables us to identify three key factors that determine digital authority on Twitter: ideology, political initiative, and the career of political actors. Also, the external sociopolitical context must be added as an explanatory factor, because it has a remarkable impact on the digital political discussion. These findings open up new ways to understand the functioning and consequences of the digital political debate and enable us to expand the existing knowledge about the role that political actors play in the dynamics of digital political communication.

\section{Funding}

This article is part of the research project CSO2017-88620-P, funded by the Spanish Research Agency (AEI) of the Government of Spain within the National Plan for R+D. 


\section{References}

Alonso-Muñoz, L., Marcos-García, S., \& Casero-Ripollés, A. (2016). Political leaders in (inter) action. Twitter as a strategic communication tool in electoral campaigns. Trípodos, (39), 71-90.

Barberá, O., Barrio, A., \& Rodríguez-Teruel, J. (2019). New parties' linkages with external groups and civil society in Spain: A preliminary assessment. Mediterranean Politics, 24(5), 646-664. https://doi.org/10.1080/13629395.2018.1428146

Bonacich, P. (2007). Some unique properties of eigenvector centrality. Social Networks, 29(4), 555-564. https://doi.org/10.1016/j.socnet.2007.04.002

Buccoliero, L., Bellio, E., Crestini, G., \& Arkoudas, A. (2020). Twitter and politics: Evidence from the US presidential elections 2016. Journal of Marketing Communications, 26(1), 88-114. https://doi.org/10.1080/13527266.2018.1504228

Casero-Ripollés, A. (2020). Influence of media on the political conversation on Twitter: Activity, popularity, and authority in the digital debate in Spain. Icono 14, 18(1):33-57. https://doi.org/10.7195/ri14.v18i1.1527

Casero-Ripollés, A. (2018). Research on political information and social media: Key points and challenges for the future. El profesional de la información, 27(5), 964-974. https://doi.org/10.3145/epi.2018.sep.01

Casero-Ripollés, A., Micó-Sanz, J. L., \& Díez-Bosch, M. (2020). Digital public sphere and geography: The influence of physical location on Twitter's political conversation. Media and Communication, 8(4), 96-106. http://dx.doi.org/10.17645/mac.v8i4.3145

Castells, M. (2013). Communication power. Oxford: Oxford University Press.

Cha, M., Haddadi, H., Benevenuto, F., \& Gummadi, K. (2010). Measuring user influence in twitter: The million follower fallacy. In: Proceedings of the International AAAI Conference on Web and Social Media, 4(1).

Chadwick, A. (2017). The hybrid media system: Politics and power. Oxford: Oxford University Press.

Chadwick, A., \& Stromer-Galley, J. (2016). Digital media, power, and democracy in parties and election campaigns: Party decline or party renewal? The International Journal of Press/Politics, 21(3), 283-293. http://doi.org/10.1177/1940161216646731

Dagoula, C. (2019). Mapping political discussions on Twitter: Where the elites remain elites. Media and Communication, 7(1), 225-234.

http://dx.doi.org/10.17645/mac.v7i1.1764

Enli, G. (2017). Twitter as arena for the authentic outsider: exploring the social media campaigns of Trump and Clinton in the 2016 US presidential election. European journal of communication, 32(1), 50-61. https://doi.org/10.1177/0267323116682802 
Fazekas, Z., Popa, S. A., Schmitt, H., Barberá, P., \& Theocharis, Y. (2020). Elite-public interaction on Twitter: EU issue expansion in the campaign. European Journal of Political Research. https://doi.org/10.1111/1475-6765.12402

Feenstra, R. A., Tormey, S., Casero-Ripollés, A., \& Keane, J. (2017). Refiguring democracy: The Spanish political laboratory. New York: Taylor \& Francis.

Gruzd, A., \& Wellman, B. (2014). Networked Influence in Social Media: Introduction to the Special Issue. American Behavioral Scientist, 58(10), 1251-1259. https://doi.org/10.1177/0002764214527087

Habermas, J. (2006). Political communication in media society: Does democracy still enjoy an epistemic dimension? The impact of normative theory on empirical research. Communication Theory, 16(4), 411-426. https://doi.org/10.1111/j.14682885.2006.00280.x

Hepp, A. (2019). Deep Mediatization. New York: Routledge.

Jungherr, A. (2014). Twitter in politics: a comprehensive literature review. Available at SSRN 2865150.

Larsson, A. O., \& Moe, H. (2012). Studying political microblogging: Twitter users in the 2010 Swedish election campaign. New Media \& Society, 14(5), 729-747. https://doi.org/10.1177/1461444811422894

López-García, G. (2016). 'Nuevos’ y ‘viejos' liderazgos: la campaña de las elecciones generales españolas de 2015 en Twitter. Communication \& Society, 29(3), 149-168. https://doi.org/10.15581/003.29.3.149-168

López-Meri, A., Marcos-García, S., \& Casero-Ripollés, A. (2017). What do politicians do on Twitter? Functions and communication strategies in the Spanish electoral campaign of 2016. El profesional de la información, 26(5), 795-804.

https://doi.org/10.3145/epi.2017.sep.02

Marcos-Marne, H., Plaza-Colodro, C., \& Freyburg, T. (2020). Who votes for new parties? Economic voting, political ideology and populist attitudes. West European Politics, 43(1), 1-21. https://doi.org/10.1080/01402382.2019.1608752

McCombs, M., \& Valenzuela, S. (2020). Setting the agenda: Mass media and public opinion. Cambridge: Polity.

McGregor, S. C. (2018). Personalization, social media, and voting: Effects of candidate self-personalization on vote intention. New media \& society, 20(3), 1139-1160. https://doi.org/10.1177/1461444816686103

Micó, J.-L., \& Carbonell, J.-M. (2017). The Catalan Political Process for Independence: An Example of the Partisan Media System. American Behavioral Scientist, 61(4), 428440. https://doi.org/10.1177/0002764217693277 
Mora-Cantallops, M., Sánchez-Alonso, S., \& Visvizi, A. (2019). The influence of external political events on social networks: The case of the Brexit Twitter Network. Journal of Ambient Intelligence and Humanized Computing, 1-13.

https://doi.org/10.1007/s12652-019-01273-7

Orriols, L., \& Cordero, G. (2016). The breakdown of the Spanish two-party system: the upsurge of Podemos and Ciudadanos in the 2015 general election. South European Society and Politics, 21(4), 469-492. https://doi.org/10.1080/13608746.2016.1198454

Page, L., Brin, S., Motwani, R., \& Winograd, T. (1999). The PageRank citation ranking: Bringing order to the web. Stanford InfoLab.

Probst, F., Grosswiele, L., \& Pfleger, R. (2013). Who will lead and who will follow: Identifying Influential Users in Online Social Networks. Business \& Information Systems Engineering, 5(3), 179-193. http://doi.org/10.1007/s12599-013-0263-7

Sobieraj, S., Masullo, G. M., Cohen, P. N., Gillespie, T., \& Jackson, S. J. (2020). Politicians, Social Media, and Digital Publics: Old Rights, New Terrain. American Behavioral Scientist, 64(11), 1646-1669. https://doi.org/10.1177/0002764220945357

Tong, J. \& Zuo, L. (2021). Dialoguing with Data and Data Reduction: An Observational, Narrowing-Down Approach to Social Media Network Analysis. Journalism and Media, 2 (1), 14-29. https://doi.org/10.3390/journalmedia2010002

Tsatsou, P., \& Zhao, Y. (2016). A "two-level social capital analysis" of the role of online communication in civic activism: Lessons from the role of Facebook in the Sunflower Movement. Social Media+ Society, 2(4), https://doi.org/10.1177/2056305116671967.

Valente, T. W., \& Pumpuang, P. (2007). Identifying opinion leaders to promote behavior change. Health Education \& Behavior, 34(6), 881-896.

https://doi.org/10.1177/1090198106297855

Van Aelst, P., Sheafer, T., \& Stanyer, J. (2012). The personalization of mediated political communication: A review of concepts, operationalizations and key findings. Journalism, 13(2), 203-220. https://doi.org/10.1177/1464884911427802

Van Dijck, J. (2013). The culture of connectivity: A critical history of social media. Oxford: Oxford University Press.

Van Dijck, J., Poell, T., \& De Waal, M. (2018). The platform society: Public values in a connective world. Oxford: Oxford University Press.

Vergeer, M., Hermans, L., \& Sams, S. (2013). Online social networks and micro-blogging in political campaigning: The exploration of a new campaign tool and a new campaign style. Party politics, 19(3), 477-501. https://doi.org/10.1177/1354068811407580

Xu, W. W., Sang, Y., Blasiola, S., \& Park, H. W. (2014). Predicting opinion leaders in Twitter activism networks: The case of the Wisconsin recall election. American Behavioral Scientist, 58(10), 1278-1293. https://doi.org/10.1177/0002764214527091 


\section{Notes}

[1] Percentage of vote obtained by the Spanish political forces after the general elections of December 2015. Source: Ministry of Home Affairs of the Spanish Government http://elecciones.mir.es/resultadosgenerales2015/congreso/\#/ES201512-CON-ES/ES 